\title{
Disk harrow operational performance in three engine rotation speeds
}

\author{
Desempenho operacional de uma grade aradora em três rotações de \\ trabalho do motor
}

\section{Tiago Pereira da Silva CORREIA ${ }^{1}$; Saulo Fernando Gomes de SOUSA ${ }^{2}$; Leandro Augusto Felix TAVARES ${ }^{3}$; Paulo Roberto Arbex SILVA²; Neilor Bugoni RIQUETTI²}

\begin{abstract}
${ }^{1}$ Autor para correspondência; Eng ${ }^{\circ}$ Agronomo; Universidade Estadual Paulista Júlio de Mesquita Filho; Departamento de Egenharia Rural; Doutorando no programa de pós-graduação Energia na Agricultura; Rua José Barbosa de Barros, 1780, cep 18610-307, Botucatu-SP; correiagoueg@hotmail.com

2 Eng ${ }^{\circ}$ Agronomo; Universidade Estadual Paulista Júlio de Mesquita Filho; saulo@fca.unesp.br; neilorbugoni@yahoo.com.br; arbex@fca.unesp.br

${ }^{3} \mathrm{Eng}^{\circ}$ Agrícola e Ambiental; Universidade Federal dos Vales do Jequitinhonha e Mucuri; leandro.tavares@ufvjm.edu.br
\end{abstract}

Recebido em: 09-09-2014; Aceito em: 16-03-2015

\begin{abstract}
Even with the current techniques of conservation tillage, mobilization is still a widely used practice, either in initial preparation as in reform of agricultural areas. In this context the harrows are widely used, mainly because of the good working capacity and high efficiency in tillage soil. Thus, this study aimed to evaluate the operating performance of a disc harrow in clay soil using different spins. The experiment was conducted at the Experimental Farm Lageado, belonging to the Faculty of Agricultural Sciences - UNESP Botucatu - SP. For accomplishment of the tillage was used a disk harrow, mark Tatu Marchesan model GAICR off-set, with a cutting width of $2.57 \mathrm{~m}$ and consists of 20 cut disks of $0,71 \mathrm{~m}$ (28 inches) spaced at $0.27 \mathrm{~m}$. To exert traction the disk harrow was used of tires tractor John Deere brand, model JD6600 with power $91.48 \mathrm{~kW}$ (121 hp) engine. The used treatments were three engine revolutions, $157 \mathrm{rad} \mathrm{s}^{-1}$ (1500 rpm), $189 \mathrm{rad} \mathrm{s}^{-1}$ (1800 rpm) and $220 \mathrm{rad} \mathrm{s}^{-1}(2100 \mathrm{rpm})$, and evaluated the working speeds achieved, effective field capacity, operational fuel consumption, working depth of the disc harrow, skating wheels of the tractor and drawbar force. The results indicated that most job rotation provided lower fuel consumption and greater field capacity. However, the increase in speed of work provided a reduction of working depth of the discs of the harrow.
\end{abstract}

Additional keywords: fuel consumption; soil preparation; velocity; working depth.

\begin{abstract}
Resumo
Mesmo nos dias atuais com técnicas conservacionistas de preparo do solo, a mobilização ainda é uma prática muito utilizada, seja em preparo inicial, seja em reforma de áreas agrícolas. Nesse contexto, as grades agrícolas são muito utilizadas, principalmente por apresentarem boa capacidade de trabalho e elevado rendimento nos preparos de solo. Desta forma, o presente trabalho teve como objetivo avaliar o desempenho operacional de uma grade aradora em solo argiloso utilizando diferentes rotações de trabalho no motor. $\mathrm{O}$ experimento foi realizado na Fazenda Experimental Lageado, pertencente à Faculdade de Ciências Agronômicas - UNESP de Botucatu - SP. Para a realização do preparo do solo, foi utilizada uma grade, marca Tatu Marchesan, modelo GAICR off-set, com largura de corte de 2,57 m e constituída por 20 discos recortados de $0,71 \mathrm{~m}$ (28 polegadas), espaçados de $0,27 \mathrm{~m}$. Para tracionar a grade, foi utilizado trator de pneus marca John Deere, modelo JD6600, com potência de 91,48 kW (121 cv) no motor. Os tratamentos utilizados foram três rotações do motor, $157 \mathrm{rad} \mathrm{s}^{-1}(1500 \mathrm{rpm}), 189 \mathrm{rad} \mathrm{s}^{-1}(1800 \mathrm{rpm})$ and $220 \mathrm{rad} \mathrm{s}^{-1}(2100 \mathrm{rpm})$, sendo avaliados as velocidades de trabalho alcançadas, a capacidade de campo efetiva, o consumo operacional de combustível, a profundidade de trabalho da grade, a patinagem dos rodados do trator, a força de tração requerida e a potência na barra de tração. Os resultados obtidos indicaram que a maior rotação de trabalho proporcionou menor consumo de combustível e maior capacidade de campo. Porém, o aumento da rotação de trabalho proporcionou redução da profundidade de trabalho dos discos da grade.
\end{abstract}

Palavras-chave adicionais: consumo de combustível; preparo de solo; profundidade de trabalho; velocidade de deslocamento.

\section{Introduction}

In modern agriculture, agricultural machines occupy a prominent place both in production costs composition, as on energy demand for agricultural operations. Machinery proper selection and correct use are of fundamental interest to reduce agricultural machinery energy demand (Jasper \& Silva, 2013). Among the different cropping systems, conservative and conventional, the conventional tillage system is one of the activities with higher energy costs in the grain production system (Sá et al., 2013). 
In addition to tractor/implement set correct selection to perform the farming operation, it is essential that this is done at soil field capacity right time, with correct settings in engine speed, gearbox transmission ratio, tires inflation pressure and tractor ballasting (Serrano, 2007).

Frantz et al. (2014) states that transmission speed is performed by a set of elements that guarantees the engine power transfer to the hydraulic system, TDP and tractor driving wheels, with engine speed having direct relation with fuel consumption and power being available to the implement, favoring or limiting the operation to be performed quality.

According to Cortez et al. (2008), what basically affects fuel consumption in tillage equipment use is the increase in power consumption by increasing the working speed. Silveira et al. (2013) stated that within a same operating speed and varying the engine speed, there are significant increases in hourly fuel consumption, which range between 7 $44 \%$, from the lowest to the highest engine speed operation for sowing example. In general, Gamero et al. (1986) reported that in soil tillage operations, fuel consumption is about $30 \%$ of the hourly cost of an agricultural tractor.

In conventional operations, Stolf et al. (2010) reported that harrows are one of the most used implement class for tillage in the preparation for planting. Usable both in primary and in secondary preparation, the most commonly used justifications for soil preparation with this implement type is the weed control, plant residues management, soil aeration and porosity improvement, a good seedbed preparation and improving soil physical conditions.

In Brazil, among the operations of soil preparation included in sugar cane cultivation system, it is estimated that about one million hectares per year are mobilized with harrows for reed bed reform. Considering three harrowing per unit area, along with the harrowing sum carried out in areas cultivated with corn, it is equivalent to approximately 2.700 turns around the Earth, demonstrating harrows importance in tillage systems (Stolf et al., 2010).

As with other implements, harrows operational review, according to Serrano (2007), can be performed based on fuel consumption per hectare measurement, which is the main technical indicator in the agricultural machinery efficiency use assessment, since it demonstrates the involvement of the several variables that affect fuel supplied to the engine transformation efficiency, during the work done by the implement.

Using a harrow in conventional tillage system, Tavares et al. (2012) described that the operating fuel consumption is $20.9 \%$ lower when compared to reduced tillage system using chisel.

Within the present context, this work aims to evaluate the operating performance of a harrow in clay soil using different engine work speeds.

\section{Material and methods}

The test was conducted in the agricultural year of 2010/2011, at the Lageado Experimental Farm, which belong to the Faculty of Agricultural Sciences - UNESP, located in the municipality of Botucatu - SP, in the central west region of São Paulo state, with the approximate geographical coordinates of Latitude $22^{\circ} 51^{\prime} \mathrm{S}$ and longitude $48^{\circ} 26^{\prime} \mathrm{W}$ Greenwich, average altitude of 770 meters and an average declivity of $4.5 \%$.

The experimental area soil was classified as Dystrophic Red Nitosol, according to EMBRAPA (1999) classification. Approximately 90 days before the test, corn was harvested in the experimental area, providing to the experimental area soil $8 \mathrm{t} \mathrm{ha}^{-1}$ of cover with crop residues and spontaneous cover vegetation, which consisted predominantly of Brachiaria decumbens and Panicum maximum. For soil granulometric characterization, were collected four samples at a depth of $0-20 \mathrm{~cm}$, resulting in a composite sample that was subjected to granulometric analysis, according to SBCS (2004) procedure. The results of this analysis are shown in Table 1.

Table 1 - Experimental area granulometric analysis for the depth of 0-20 cm.

\begin{tabular}{cccc}
\hline Sand $\left(\mathrm{g} \mathrm{kg}^{-1}\right)$ & Clay $\left(\mathrm{g} \mathrm{kg}^{-1}\right)$ & Silt $\left(\mathrm{g} \mathrm{kg}^{-1}\right)$ & Texture \\
\hline 165 & 450 & 385 & Clayey \\
\hline
\end{tabular}

The experimental design was a randomized complete block design with 3 treatments and 4 replicates, for a total of 12 experimental plots. Used treatments were three different engine speeds, with $157 \mathrm{rad} \mathrm{s}^{-1}(1500 \mathrm{rpm}), 189 \mathrm{rad} \mathrm{s}^{-1}(1800 \mathrm{rpm})$ and $220 \mathrm{rad} \mathrm{s}^{-1}(2100 \mathrm{rpm})$, all in B1 gear escalation. Plots were dimensioned to be $20 \mathrm{~m}$ long and with $3.5 \mathrm{~m}$ overall width, spaced $15 \mathrm{~m}$ from each other, to perform the required maneuvers and stabilizing the tractor-harrow set.

In the experiment implementation and conduct, a John Deere brand tractor was used, 6600 model, with front wheel auxiliary traction (4x2 TDA), with $91.48 \mathrm{~kW}(121 \mathrm{hp})$ engine power.

To perform the tillage, a Marchesan GAICR model Intermediate Off-Set harrow with 20 disks cut in both sections, spaced at $0.27 \mathrm{~m}, 0,71 \mathrm{~m}$ (28 inches) in diameter, cutting width of $2.57 \mathrm{~m}$ and work depth of 0.12 to $0.20 \mathrm{~m}$ were used.

To determine harrow working depth, the surface profilometer method was used, as described by Lanças \& Benez (1987). Vertical soil displacement in the mobilized area was assessed, in which the natural profile, background and soil elevation survey 
was performed.

First, readings were taken at the soil surface profile, prior to the preparation. After preparation, readings were performed to determine soil swelling caused by harrows; then, a groove was manually opened with the aid of a mattock, removing any soil mobilized by the active equipment organs, in order to evaluate the subsurface soil profile, at the same location where the surface profile and the swelling reading was performed. To properly schedule and ensure that the three readings were taken at the same location, two piles embedded into the soil were used, one on each side, which also served as profilometer support base.

To determine wheels slipping, pulse generators from $S \& E$ tests and measurement Instrument brand, IGoE-60-U12V model, was used, which performed rotary motion or linear displacements conversion into electrical pulses, generating 60 pulses per tractor wheelset revolution. Wheels pulse generators were fixed in the tractor wheels center.

To determine the average bar traction force (Fbt), a Sodmex brand load cell, N-400 model was used, with a capacity of $100 \mathrm{kN}$ and sensitivity of $2.16 \mathrm{mV} \mathrm{V}^{-1}$.

Tractor fuel consumption per hour (Chc) measurement was performed using the "Flowmate" brand flowmeter, Oval M-III model, with accuracy of $0.01 \mathrm{~L}$. This flowmeter generates a pulse at every milliliter $(\mathrm{mL})$ of fuel consumed by tractor.

For the acquisition and tracking of the signals obtained by sensors in the fuel supply system and the load cell, a panel with indicator electronic instruments panel of "MICRO-P" type.

The effective working speed (Ve) of the tractor-harrow set, which is the actual displacement speed of the set operating in the plot, was obtained by Equation (1), with the rout time recorded with the aid of a digital stopwatch.

$V e=(\Delta S / \Delta T) 3.6$

Where $V e$ is the effective working speed $\left(\mathrm{km} \mathrm{h}^{-1}\right) \Delta S$ the plot distance $(\mathrm{m})$ and $\Delta \mathrm{T}$ the rout time $(\mathrm{s})$.

Having the Fbt and Ve data, the average power required in the traction bar was calculated (Pbt) according to Equation (2), suggested by Lopes et al. (2010).
$\mathrm{Pbt}=\mathrm{Fbt} \times(\mathrm{Ve} / 3.6)$

Where $\mathrm{Pbt}$ is the average power required in the traction bar $(\mathrm{kW})$, Fbt is the average force in the bar $(\mathrm{kN})$, obtained by the load cell and MICRO-P panel, and Ve is the effective working speed $\left(\mathrm{km} \mathrm{h}^{-1}\right)$.

The effective field capacity (Equation 3), which is the amount of hectares per hour worked by the set, was calculated through the effective tractor speed and the implement actual width.

$\mathrm{Cce}=(\mathrm{L} \times \mathrm{Ve}) / 10$

Where Cce is the effective field capacity $\left(\right.$ ha $\left.h^{-1}\right), L$ is the working width $(\mathrm{m})$ and $\mathrm{Ve}$ is the effective working speed $\left(\mathrm{km} \mathrm{h}^{-1}\right)$.

The operational fuel consumption, which represents the fuel consumption per worked area, was obtained from the relation between hourly fuel consumption and effective field capacity, according to Equation (4).

$\mathrm{COC}=\mathrm{Chc} / \mathrm{Cce}$

Where $\mathrm{COC}$ is the operational fuel consumption ( $L$.ha $\left.{ }^{-1}\right)$, Chc the hourly fuel consumption $\left(\mathrm{L} \mathrm{h}^{-1}\right)$ and Cce the effective field capacity $\left(\right.$ ha $\left.^{-1}\right)$.

The results were submitted to analysis of variance at $5 \%$ probability by $\mathrm{F}$ test, and the treatment means were compared by Tukey test at 5\% significance level.

\section{Results and discussions}

As shown in Table 2, the results of operational fuel consumption (COC), effective field capacity (Cce), effective work speed and harrow work depth showed significant differences for the different used engine speeds.

The $220 \mathrm{rad} \mathrm{s}^{-1}(2100 \mathrm{rpm})$ rotation had most effective working speed results, $3.65 \mathrm{~km} \mathrm{~h}^{-1}$, higher Cce, $0,91 \mathrm{ha} \mathrm{h}^{-1}$, and reduced COC, $17.25 \mathrm{~L}^{\mathrm{h}} \mathrm{ha}^{-1}$. In this rotation, the $\mathrm{COC}$ was of 47.4 and $13.5 \%$ lower than the engine COC in $157 \mathrm{rad} \mathrm{s}^{-1}$ (1500 rpm) and $189 \mathrm{rad} \mathrm{s}^{-1}$ (1800 rpm) regime, respectively. This COC result at $220 \mathrm{rad} \mathrm{s}^{-1}(2100 \mathrm{rpm})$ is similar to that found by Salvador et al. (2009), in $16.41 \mathrm{~L} \mathrm{ha}^{-1}$.

Table 2 - Effective work speed, effective field capacity, operational fuel consumption, average work depth, traction bar average force and front and rear slipping in function of engine rotation.

\begin{tabular}{lllllcccc}
\hline $\begin{array}{c}\text { Engine } \\
\text { rotation } \\
\left(\mathrm{rad} \mathrm{s}^{-1}-\mathrm{rpm}\right)\end{array}$ & $\begin{array}{c}\mathrm{k}^{1} \mathrm{Ve} \\
\left.\mathrm{km} \mathrm{h}^{-1}\right)\end{array}$ & $\begin{array}{c}{ }^{2} \mathrm{Cce} \\
(\mathrm{ha} \mathrm{h}-1)\end{array}$ & $\begin{array}{c}{ }^{3} \mathrm{COC} \\
(\mathrm{L} \mathrm{ha})\end{array}$ & $\begin{array}{c}\text { Work depth } \\
(\mathrm{cm})\end{array}$ & $\begin{array}{c}\text { Average } \\
\text { force } \\
(\mathrm{N})\end{array}$ & $\begin{array}{c}\text { Average } \\
\text { power } \\
(\mathrm{kW})\end{array}$ & \multicolumn{2}{c}{ Slipping (\%) } \\
\hline $157-1500$ & $2.50 \mathrm{c}$ & $0.62 \mathrm{c}$ & $32.85 \mathrm{a}$ & $17.7 \mathrm{a}$ & $15275 \mathrm{a}$ & $10.57 \mathrm{c}$ & $14.2 \mathrm{a}$ & $14.4 \mathrm{a}$ \\
$189-1800$ & $3.05 \mathrm{~b}$ & $0.76 \mathrm{~b}$ & $19.95 \mathrm{~b}$ & $17.5 \mathrm{a}$ & $15012 \mathrm{a}$ & $12.65 \mathrm{~b}$ & $14.4 \mathrm{a}$ & $14.4 \mathrm{a}$ \\
$220-2100$ & $3.65 \mathrm{a}$ & $0.91 \mathrm{a}$ & $17.25 \mathrm{c}$ & $13.1 \mathrm{~b}$ & $14100 \mathrm{a}$ & $14.23 \mathrm{a}$ & $15.2 \mathrm{a}$ & $14.9 \mathrm{a}$ \\
\hline C.V. $(\%)$ & 2.61 & 2.56 & 4.3 & 11.12 & 6.4 & 0.68 & 7.82 & 6.27 \\
\hline
\end{tabular}

${ }^{1}$ Effective work speed. ${ }^{2}$ Effective field capacity. ${ }^{3}$ Operational fuel consumption. Means followed by the same letter in the column do not differ by $t$ test at $5 \%$ probability.

While assessing operating performance of tandem and light off-set harrow with 22" and 24" 
and $1.10 \mathrm{ha} \mathrm{h}^{-1}$. The speeds found in this study are different from those mentioned in lower values, what can be explained due to the used harrow having $0,71 \mathrm{~m}$ ( 28 inches) diameter disks, which are heavier and reach deeper work depth. Cce lower values in this study can be justified and discussed in function of used harrow lower speeds and work width. A width of $2.57 \mathrm{~m}$ and maximum speed of $3.65 \mathrm{~km} \mathrm{~h}^{-1}$ at $220 \mathrm{rad} \mathrm{s}^{-1}(2100 \mathrm{rpm})$ are limiting factors to Cce. Harrows used by the authors had a width of $2.8 \mathrm{~m}$ and speed of up to $5.76 \mathrm{~km} \mathrm{~h}^{-1}$.

Similar Cce results were found by Silveira et al. (2006), who found for harrow preparation the effective field capacity of $0.86 \mathrm{ha} \mathrm{h}^{-1}$.

The harrow work depth, which is a factor directly related to operation quality, was lower for $220 \mathrm{rad} \mathrm{s}^{-1}$ (2100 rpm) rotation. The lowest depth, $13.1 \mathrm{~cm}$, can be explained due to $220 \mathrm{rad} \mathrm{s}^{-1}(2100$ rpm) rotation having caused higher harrow work speed $\left(3.65 \mathrm{~km} \mathrm{~h}^{-1}\right)$. In higher work speeds, harrow disks tend to deepen less and require less traction force and bar power, resulting in lower COC. These results are equivalent to those found by Levien et al. (2003) and Cunha et al. (2011), who also worked with harrow disks.
Pequeno et al. (2012), while evaluating the performance of a tractor-harrow set in the Brazilian northeastern semi-arid working in $214 \mathrm{rad} \mathrm{s}^{-1}$ (2040 rpm) rotation, authors found that for higher work speed there was a significant work depth reduction, of $0.11 \mathrm{~m}$ to $0.09 \mathrm{~m}$, explained as a harrow floating effect. It was also found that the increase in speed requires more power in the traction bar, with traction force not being changed.

Assuming that the engine rotation speed and the effective work speed may be decision making questions in the harrowing operation, the choice of $220 \mathrm{rad} \mathrm{s}^{-1}(2100 \mathrm{rpm})$ rotation and $3.65 \mathrm{~km} \mathrm{~h}^{-1}$ enables fuel economy and higher worked area amount per unit time, which are desirable results to reduce operational costs. In contrast, the increase in effective speed reduces harrow work depth, from $2.5 \mathrm{~km} \mathrm{~h}^{-1}$ (157 rad s${ }^{-1} ; 1500 \mathrm{rpm}$ ) to $3.65 \mathrm{~km} \mathrm{~h}^{-1}$; the depth is reduced in approximately $26 \%$, going from 17.7 to $13.1 \mathrm{~cm}$. The consequence is tillage with compromised quality, being only superficially mobilized, as the profilometer result shown in Figure 1.

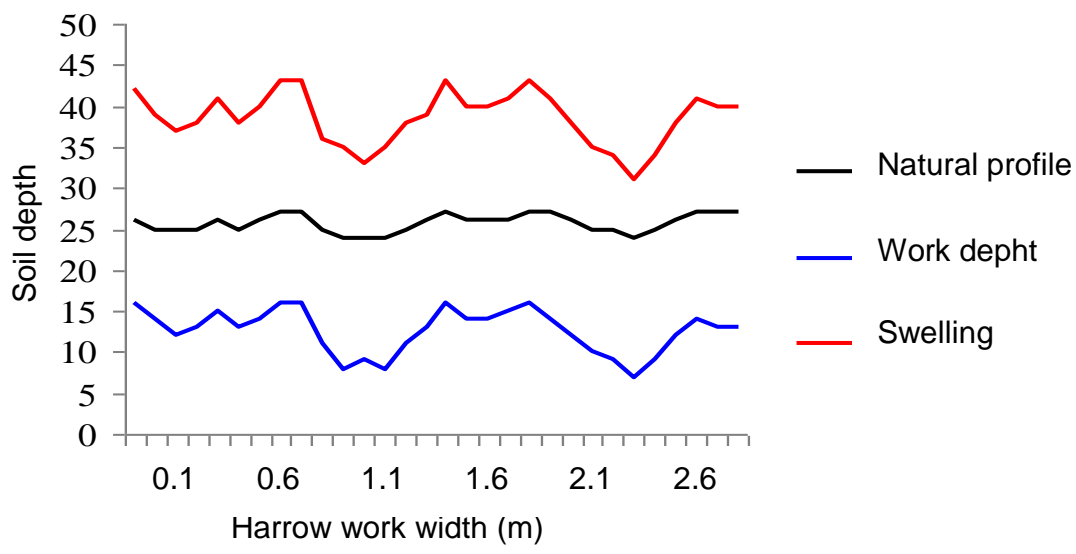

Figure 1 - Graphical representation of work depth, swelling and soil natural profile prepared with disk harrow in $220 \mathrm{rad} \mathrm{s}^{-1}(2100 \mathrm{rpm})$ engine rotation and effective speed of $3.65 \mathrm{~km} \mathrm{~h}^{-1}$.

Although effective speeds were significantly different for the three engine speeds, and work depth was lower at $220 \mathrm{rad} \mathrm{s}^{-1}(2100 \mathrm{rpm})$, average power on the traction bar results were not significantly different between rotations. However, bar average power results differed significantly between the three rotations, being higher for $220 \mathrm{rad} \mathrm{s}^{-1}$ (2100 rpm). Lopes et al. (2010) stated that the traction bar power is related to traction force and operation speed, the latter influenced by work depth. Thus, the larger the work depth, higher the traction force, lower the movement speed and higher is the power required in the bar. However, the results have not accurately culminated in all relations clarified by the authors, and also in Grotta et al. (2008), and the higher required power at $220 \mathrm{rad} \mathrm{s}^{-1}(2100 \mathrm{rpm})$ may be related only to higher Ve, the used gear escalation (B1) and the harrow setting. Stolf et al. (2010), while studying harrows work angle, correlated dimensional characteristics and adjustments to its required power.

Tractor front and rear wheels slippage fluctuated between 14.2 and $15.2 \%$, and 14.4 and $14.9 \%$, respectively, with no significant difference between them for the three engine rotation speeds. However, the front slip slightly higher at $220 \mathrm{rad} \mathrm{s}^{-1}(2100 \mathrm{rpm})$ can also contribute to the result of higher required average power.

\section{Conclusions}

Disk harrow operating performance in clay soil enables lower fuel consumption and higher effective field capacity when $220 \mathrm{rad} \mathrm{s}^{-1}(2100 \mathrm{rpm})$ engine rotation was used. In contrast, work depth was reduced and the power required on the bar increased.

Lower engine rotation speed provides higher work depth and less power in the traction bar. 


\section{References}

Cortez JW, Ferreira BJM, Alves ADS, Moura MRD, Nagahama HJ (2011). Desempenho operacional do conjunto trator-implemento nas operações de preparo do solo. Revista Nucleus 8(12):177-184.

Cortez JW, Furlani CEA, Silva RP, Grotta DCC (2008). Efeito residual do preparo do solo e velocidade de deslocamento na operação de semeadura da Crotalária juncea. Scientia Agraria 9(3):357-362.

Cunha JPB, Reis EF, Couto RF, Holtz V (2011). Efeito de diferentes concentrações de biodiesel no desempenho de um trator em operação de preparo do solo. Revista Agrotecnologia 2(2):53-67.

EMBRAPA (1999) Empresa Brasileira de Pesquisa Agropecuária. Centro Nacional de Pesquisa de Solos. Sistema brasileiro de classificação de solos, Rio de Janeiro. 412 p.

Frantz UG, Schlosser JF, Farias MS, Ferigolo LF, Ebert LC (2014). Eficiência energética de um trator agrícola utilizando duas configurações de tomada de potência. Ciência Rural 44(7):1219-1222.

Gamero CA, Nakagawa J, Almeida RM (1986). Efeito do tipo de preparo do solo sobre características das sementes de milho. Revista Brasileira de Sementes 8(2):117-127.

Grotta DCC, Lopes A, Furlani CEA, Silva RP, Reis GN, Cortez JW (2008). Biodiesel etílico filtrado de óleo residual de soja: desempenho de um trator agrícola na operação de gradagem. Acta Scientiarum Agronomy 30(2):135-138.

Jasper SP, Silva PRA (2013). Estudo comparativo do custo operacional horário da mecanização agrícola utilizando duas metodologias para o estado de São Paulo. Ver. Revista Nucleus 10(2):119-126.

Lanças KP, Benez SH (1987). Avaliação da mobilização do solo na operação de subsolagem. Energia na Agricultura 2(4):25-33.

Levien R, Gamero CA, Furlani CEA (2003). Preparo convencional e reduzido em solo argiloso em diferentes condições de cobertura de inverno. Engenharia Agrícola 23(2):277-289.

Lopes A, Camara FT, Scala Júnior NL, Furlani CEA, Silva RP, Barbosa ALPB (2010). Desempenho operacional de um protótipo "aerossolo". Engenharia Agrícola 30(1):82-91.
Pequeno ID, Arcoverde SNS, Cortez JW, Garrido MS, Carvalho PGS (2012). Desempenho operacional de conjunto trator-grade em argissolo amarelo no semiárido nordestino. Revista Nucleus 9(2):83-92.

SBCS (2004) Sociedade Brasileira de Ciência do Solo. Manual de adubação e calagem para os estados do Rio Grande do Sul e Santa Catarina. Comissão de química e fertilidade do solo $-10^{\circ} \mathrm{Ed}$, Porto Alegre. 400p.

Sá JM, Urquiaga S, Jantalia CP, Soares LHB, Alves BJR, Boddey RM, Marchão RL, Vilela L (2013). Balanço energético da produção de grãos, carne e biocombustíveis em sistemas especializados e mistos. Pesquisa Agropecuária Brasileira 48(10):1323-1331.

Salvador N, Mion RL, Benez SH (2009). Consumo de combustível em diferentes sistemas de preparo periódico realizados antes e depois da operação de subsolagem. Ciência e Agrotecnologia 33(3):870-874.

Serrano JMPR (2007). Desempenho de tratores agrícolas em tração. Pesquisa Agropecuária Brasileira 42(7):1021-1027.

Silveira GM, Yanai K, Kurachi SAH (2006). Determinação da eficiência de campo de conjuntos de máquinas convencionais de preparo de solo, semeadura e cultivo. Revista Brasileira de Engenharia Agrícola e Ambiental 10(1):220-224 .

Silveira JCM, Fernandes HC, Modolo AJ, Silva SL, Trogello E (2013). Demanda energética de uma semeadora-adubadora em diferentes velocidades de deslocamento e rotações do motor. Revista Ciência Agronômica 44(1):44-52.

Stolf R, Silva JR, Gomez JAM (2010). Medida do ângulo horizontal de ataque dos discos de grade agrícolas de dupla ação e aplicação em uma propriedade agrícola. Bragantia 39(2):493-497.

Tavares LAF, Benez SH, Silva PRA (2012). Características agronômicas e demanda energética de cultivares de soja sob efeito dos sistemas de preparo do solo. Energia na Agricultura 27(4):92-108. 